\title{
Effect of Fresh or Cryopreserved Pollen on Seed Setting of Intervarietal and Interspecific Crosses of Gladiolus
}

\author{
Tul Bahadur Poon ${ }^{1}$, T.M. Rao ${ }^{2}$, P.E. Rajshekharan ${ }^{2}$, C. Aswath ${ }^{2}$ and D.P. Kumar ${ }^{3}$ \\ ${ }^{2}$ Nepal Agricultural Research Council (NARC), Khumaltar \\ ${ }^{2}$ Indian Institute of Horticultural Research (IIHR) \\ Hessaraghatta, Bangalore \\ ${ }^{3}$ University of Agricultural Sciences, GKVK, Bangalore \\ e-mail: chetpun2002@yahoo.co.in
}

\begin{abstract}
An experiment was conducted in the field of Indian Institute of Hortricultural Research, Hessaraghatta, Bangalore during August 2006 to June 2008. The experiment consisting of eight treatment combinations were laid out in ' $2 x 4$ ' factorial RCBD with 5 replications to assess seed set per capsule. The results revealed that highly significant differences were observed for number of well-developed seeds and underdeveloped seeds. Among four cross combinations 'H.S. 88-10-22 x Shobha' (27.63 well-developed seeds per capsule) and 'H.S. 84-7-11 x Shobha' (27.01 well-developed seeds per capsule) were significantly higher than those of other two cross combinations. The interaction effect of fresh pollen- cum- 'H.S.88-10-22 x Shobha' produced significantly higher number of welldeveloped seeds (41.02 per capsule) than those of the other treatment combinations. In contrast, treatment combinations viz., cryopreserved pollen- cum- 'H.S. 88-10-22 x Shobha' produced the lowest number of welldeveloped seeds (10.85 per capsule).Inclusion of fresh pollen to genotype 'Shobha' and cryopreserved pollen of H.S. 88-10-22' revealed better performances for maximum seed set per capsule.
\end{abstract}

Key words: gladiolus, cryopreserved, pollen, seeds, cross combination

\section{Introduction}

Gladiolus (Gladiolus grandiflorus Hort.) is one of the most popular ornamental bulbous flowers grown for cut flower and garden display in many parts of the world. It is a native of Mediterranean region, tropical South Africa and Asia. It is a member of family Iridaceae, subfamily Ixiodae, tribe-3, sub tribe Gladiolines. The current number of species in genus Gladiolus is 250260. Presently cultivated gladiolus hybrids (Gladiolus grandiflorus Hort.) have been developed genetically from 20-25 species out of 250 found in its native place (Misra et al. 2003). There are over 30,000 varieties evolved in gladiolus so far. These have been mostly evolved through conventional breeding (Singh 2006). Even though a large number of exotic and indigenous gladiolus cultivars with desirable vegetative and floral traits are available, yet there is a scope to improve the traits of cultivars through further breeding. Major gains of productivity increase and incorporation of other traits so far have come from conventional breeding efforts (Raghava 1999). In gladiolus various colors of flowers are available. Efforts need to be intensified to develop fragrant varieties combined with desirable traits. In spite of success of vegetative propagation in gladiolus, the development of desirable varieties with wide genetic base is possible only through sexual means. Hence, seed set is one of the most important pre-requisites for successful breeding program. However, either extremely low seed set in a few intervarietal crosses or the failures of seed set in some interspecific crosses are apparently realized major problems. Asynchrony in flowering is an impediment to plant breeders for hybridization. Hence, pollen 
storage can be one of the measures to overcome such problems. Intercrossing of asynchronous flowering genotypes, which are known to be compatible, can be accomplished by storage of pollen from the early flowering genotypes and crossing with the late flowering genotypes.

\section{Methodology}

The experiment was conducted under field condition in the block VII of Indian Institute of Horticultural Research, Hessaraghatta, Bangalore during August 2006 to June 2008. The experimental field was located at an altitude of $890 \mathrm{~m}$. The soil type of experimental site was red loam. The experiment consisted of four cross combinations, each of the cross combination was separately crossed with fresh and cryopreserved pollens. The pollen of the genotypes: Kum Kum, Shobha, Hybrid selection 88-10-22', and Psittacinus hybrid were cryopreserved for a period of 150 days in liquid nitrogen.

The first, second and third florets, which were showing color at bud stage were used for emasculation and the rest of florets from the fourth to the top were removed in order to enhance effective fertilization after being pollinated. In morning three florets to be pollinated were emasculated by removing out all the anthers with forceps without injuring the pistil. These emasculated florets were covered with perforated butter paper bags to prevent contamination by pollens from unknown sources. Using fresh and cryopreserved pollen, pollination was effected in about 48 hours after emasculation. Emasculated flowers were pollinated between 10.00 to 11.30 a.m. by gently rubbing dehisced anther against the sticky stigmatic surface. Intervarietal and interspecific crosses were made during the last week of January. After pollination, pollinated florets were covered with perforated butter paper bags and tied with soft thread. Pollinated plants were labeled. Four different spikes of the same parent were used per replication for hybridization. There were a total of eight treatments tested in $2 \times 4$ factorial RCBD with five replications. Capsules were harvested in about one month after pollination. Observations were recorded for number of well-developed seeds and underdeveloped seeds per capsule.

\section{Results and Discussion}

\section{Effect of different cross combinations on seed set}

Data on two characters, viz., number of well-developed seeds and underdeveloped seeds in Table 1 indicates that differences for both characters were highly significant among different cross combinations.

Number of well-developed seeds varied from 15.45 to 27.63 with a mean value of 21.89 . The maximum number of well-developed seeds were noticed in cross combinations, viz., Hybrid selection 88-10-22 x Shobha (27.63 per capsule) and Hybrid selection 84-7-11 x Hybrid selection 88-10-22' (27.01 per capsule). Number of well-developed seeds in these two cross combinations was statistically at par. Cross combination viz. Hybrid selection 84-7-11 x Shobha produced the minimum number of well-developed seeds (15.45 per capsule) followed by Psittacinus hybrid x Kum Kum (17.45 per capsule).

Number of underdeveloped seeds per capsule varied from 9.79 to 16.44 with a mean value of 12.55 . In cross combination viz. Hybrid selection 88-10-22 x Shobha recorded the highest number of underdeveloped seeds (16.44 per capsule) followed by Hybrid selection 84-

Table 1. Seed set per capsule as affected by different cross combinations

\begin{tabular}{l|c|c}
\hline \multicolumn{1}{c|}{ Cross combinations } & $\begin{array}{c}\text { Number of well-developed } \\
\text { seeds per capsule }\end{array}$ & $\begin{array}{c}\text { Number of underdeveloped } \\
\text { seeds per capsule }\end{array}$ \\
\hline H.S. 88 -10-22 X Shobha & 27.63 & 16.44 \\
H.S. 84-7-11 X Shobha & 15.45 & 10.32 \\
H.S. 84-7-11 X H.S. 88-10-22 & 27.01 & 13.66 \\
Psittacinus hybrid X Kum Kum & 17.45 & 9.79 \\
Mean & 21.89 & 12.55 \\
F-test & $* *$ & 1.10 \\
\hline
\end{tabular}

** Highly significant, H.S.= Hybrid selection 
Tul Bahadur Poon et al./Effect of Fresh or Cryopreserved Pollen

7-11 x Hybrid selection 88-10-22’' (13.66 per capsule). In cross combination viz., Psittacinus hybrid x Kum Kum recorded the lowest number of underdeveloped seeds (9.79 per capsule) followed by'Hybrid selection 84-7-11 x Shobha (10.32 per capsule).

\section{Interaction effect of pollen (fresh or cryopreserved) and cross combinations on seed set}

Seed set in an individual capsule as affected by pollen and cross combinations is presented in Table 2. Highly significant differences were recorded for number of well-developed and underdeveloped seeds. Number of well-developed seeds per capsule ranged from 10.85 to 41.02 with a mean of 21.89 .

The highest number of well-developed seeds (41.02 per capsule) (Table 2) was obtained in fresh pollencum-Hybrid selection 88-10-22 x Shobha followed by fresh pollen- cum- Hybrid selection 84-7-11 x Shobha (33.05 per capsule). The treatment combination viz., fresh pollen cum Hybrid selection 88-10-22 x Shobha was significantly different from the rest of the treatment combinations. The lowest number of well-developed seeds (10.85 per capsule) was obtained due to the interaction effect of cryopreserved pollen cum 'Hybrid selection 88-10-22 x Shobha' followed by cryopreserved pollen- cum -Psittacinus hybrid $\mathrm{x}$ Kum Kum (13.35 per capsule). Cross combinations viz., cryopreserved pollen cum 'Hybrid selection 88-10-22 x Shobha' was statistically at par with cryopreserved pollen-cum- Psittacunus hybrid x Kum Kum (13.35 seeds per capsule).

Number of underdeveloped seeds per capsule ranged from 8.00 to 21.53 with a mean value of 12.55 (Table 2). The interaction effect of fresh pollen and cross combination Hybrid selection 88-10-22 x Shobha produced significantly the highest number of underdeveloped seeds (21.53 per capsule) followed by fresh pollen- cum -Hybrid selection 84-7-11 x Shobha (17.76 per capsule). The interaction effect of cryopreserved pollen- cum- Psittacinus hybrid x Kum Kum produced minimum number of underdeveloped seeds (8.00 per capsule) which was on par with cryoprerved pollen- cum- Hybrid selection 88-10-22 x Shobha (8.88 per capsule), and fresh pollen- cumPsittacinus hybrid x Kum Kum (9.56 per capsule).

Table 2. Interaction effects of pollen (fresh or cryopreserved) and cross combinations on seed set per capsule

\begin{tabular}{|c|c|c|c|c|}
\hline \multirow[b]{3}{*}{ H.S. 88 -10-22 X Shobha } & \multicolumn{2}{|c|}{$\begin{array}{l}\text { Number of well-deve loped } \\
\text { seeds per capsule }\end{array}$} & \multicolumn{2}{|c|}{$\begin{array}{l}\text { Number of underdeveloped seeds } \\
\text { per capsule }\end{array}$} \\
\hline & $\begin{array}{l}\text { Fresh } \\
\text { pollen }\end{array}$ & $\begin{array}{c}\text { Cryopreserved } \\
\text { Pollen }\end{array}$ & $\begin{array}{l}\text { Fresh } \\
\text { pollen }\end{array}$ & $\begin{array}{c}\text { Cryopreserved } \\
\text { pollen }\end{array}$ \\
\hline & 41.02 & 10.85 & 21.53 & 8.88 \\
\hline H.S. 847-11 X Shobha & 33.05 & 21.56 & 17.76 & 11.57 \\
\hline H.S. $847-11$ X H.S. $88-10-22$ & 14.24 & 20.05 & 11.36 & 11.76 \\
\hline Psittacinus hyorid X Kum Kum & 20.98 & 13.35 & 9.56 & 8.00 \\
\hline Mean & \multicolumn{2}{|r|}{21.89} & \multicolumn{2}{|r|}{12.55} \\
\hline F-test & \multicolumn{2}{|r|}{$* *$} & \multicolumn{2}{|r|}{$* *$} \\
\hline C.D.@ $5 \%$ & \multicolumn{2}{|r|}{2.60} & \multicolumn{2}{|r|}{1.56} \\
\hline
\end{tabular}

** Highly significant, H.S. = Hybrid selection

Interaction effect of fresh or cryopreserved pollen and intervarietal cross combination were highly significant for the number of well-developed and underdeveloped seeds. The number of well-developed seeds ranged from 10.85 per capsule to 41.02 per capsule in the present study. Fresh pollen used in cross combination Hybrid selection 88-10-22 x Shobha gave the highest number of well-developed seeds (41.02 per capsule), which differed significantly from the rest of the treatment combinations. The lowest number of welldeveloped seeds (10.85 per capsule) was recorded in cryopreserved pollen used in Hybrid selection 88-10-
22 x Shobha and it did not differ significantly from cryopreserved pollen used in Psittacinus hybrid x Kum Kum. Koopowitz et al. (1984) observed 70 seeds per capsule when cryopreserved pollen was used in different cross combinations of gladiolus. However, cryopreserved pollen used in H.S. 84-7-11 X H.S. 8810-22 had higher well-developed seeds (20.05 per capsule) than fresh pollen used in the same cross combination with seeds (14.24 per capsule). Rajasekharan et al. (1994) observed comparatively high number of seeds per capsule under fresh pollen used in cross combinations viz. Sapna x Meera, Shobha 
x Meera and Meera x Aspara. Therefore, the result of present study is in close conformity with them even though the number of seed per capsule was slightly low. Causes for viability reduction in vitro after cryogenic storage could be due to inherent genotypic differences in response to cryopreservation and crossing time of season (Towill 1985).

Storage of pollen is essential for cross pollination between cultivars and species with different flowering times and between plants grown in different seasons. Cryogenic storage of pollen could enhance breeding efficiency through better management of the haploid gene pool resources. Pollen parents could be available throughout the breeding program, ensuring guaranted supply at the time of peak stigma receptivity. Fresh pollen is to be used in the event of synchronous flowering genotypes but the use of cryopreserved pollen is crucially important for hybridization in case of asynchronous flowering genotypes.

\section{References}

Koopowitz, H., R. Voss and C. O’neil. 1984. Long- term storage of gladiolus pollen. HortScience - 19 (4): 513-514.

Misra, R.L., B. Singh and S.K. Palai. 2003. Gladiolus. In: Commercial flowers. (Eds. T.K. Bose, L.P. Yadav, P. Pal, V.A. Parthasarthy and P. Das). NAYA UDYOG 206 Bidhan Sarani Kolkata 700006, 2:1-112.

Raghava, S.P.S. 1999. Genetic improvement of ornamentals in India. Journal of Ornamental Horticulture, New Series 2 (1): 1-6.

Rajasekharan, P.E., T.M. Rao, T. Janakiram and S. Ganeshan. 1994. Freeze preservation of gladiolus pollen. Euphytica 80:105-109.

Singh, A.K. 2006. Gladiolus. In: Flower crops cultivation and management. Publishing Agency Pitampura, New Delhi-110088 Pp. 147-166.

Towill, L.E. 1985. Low temperature and freeze/vacuumdrying preservation of pollen. In: Cryopersevation of plant cells and organs. (Eds. K.K. Kartha). CRC Press, Inc., Boca Rotan, Florida, pp.171. 